\title{
A Synthetic Peptide Derived from the Sequence of a Type I Collagen Receptor Inhibits Type I Collagen-mediated Platelet Aggregation
}

\author{
Thomas M. Chiang and Andrew H. Kang \\ Veterans Affairs Medical Center, Memphis, Tennessee 38104; and the Department of Medicine and Department of Biochemistry, \\ University of Tennessee-Memphis, Memphis, Tennessee 38104
}

\begin{abstract}
A synthetic peptide-1, an 18 amino acid residue peptide derived from a hydrophilic domain of a cloned platelet type I collagen receptor, was used to study the role of the receptor on types I and III collagen-induced platelet aggregation and the release of ATP. The peptide inhibits the type I, but not the type III, collagen-induced platelet aggregation and the release of ATP in a dose-dependent manner. The $\left[{ }^{125}\right.$ I]peptide-1 specifically binds to type I collagen-coated microtiter wells in a dose-dependent manner (with $K_{\mathrm{d}}=\mathbf{1 0}$ $\mathrm{nM})$. The binding of $\left[{ }^{125} \mathrm{I}\right]$ peptide- 1 can be inhibited by an excess of unlabeled peptide- 1 suggesting that the binding is specific. The labeled peptide-1 does not bind to type III collagen-coated microtiter wells. Results from an enzymelinked immunosorbent assay show that the peptide reacts with the poly- and monoclonal antibodies raised against the purified platelet type I collagen receptor $\left(M_{\mathrm{r}} 65 \mathrm{kD}\right)$. The peptide also inhibits the adhesion of platelets on type I collagen matrix and rabbit aortic segments in a dose-dependent manner. These results suggest that the reactive site of the platelet receptor for type I collagen resides in this portion of the molecule. (J. Clin. Invest. 1997. 100:2079-2084.) Key words: platelet aggregation - platelet collagen receptor • platelet aggregation inhibitor $\cdot$ collagen
\end{abstract}

\section{Introduction}

Two groups of platelet proteins have been proposed as collagen receptors that can initiate platelet aggregation through collagen receptor interaction. One group, represented by members of the integrin family, in which the receptor contains heterodimers, includes glycoprotein Ia-IIa $(\alpha 2 \beta 1)$ (1) and glycoprotein $(\mathrm{GP})^{1}$ IIb-IIIa $(\alpha \operatorname{IIb} \beta 3)(2)$. The other group, composed of single chain or proteins with homodimers, includes a $65 \mathrm{kD}$ protein described by our laboratory (3), a $85 / 90 \mathrm{kD}$ protein (4), GP IV (5), and GP VI (6). The functional relationship among these proteins is unknown, but different experimental ap-

Address correspondence to Thomas M. Chiang, Research Service (151), VA Medical Center, 1030 Jefferson Ave., Memphis, TN 38104. Phone: 901-523-8990 ext. 7608; FAX: 901-577-7273; E-mail: tchiang@ utmem2.utmen.edu

Received for publication 13 May 1997 and accepted in revised form 22 August 1997.

1. Abbreviations used in this paper: GP, glycoprotein; PRP, plateletrich plasma.

The Journal of Clinical Investigation

Volume 100, Number 8, October 1997, 2079-2084

http://www.jci.org proaches may have led to description of a large number of putative collagen receptors. For example, in the presence of $\mathrm{Mg}^{2+}$, the adherence of platelets to collagen is mediated by platelet glycoprotein Ia-IIa (1), but in the absence of metal ions, platelets adhere to many nonintegrin proteins as described above. For the integrin platelet collagen receptor, the reactive site of the ligands is thought to reside in a tetra peptide sequence, Asp-Gly-Glu-Ala (DGEA) of type I collagen (7) or Arg-Gly-Asp-Ser (RGDS) of fibronectin (8-10). The RGDS sequence has also been found in type I collagen, but it is cryptic in native collagen and exposed only on proteolytic degradation and denaturation (11). The active binding site on integrins, however, has not been defined.

Previously, we have isolated and purified a receptor for type I collagen $\left(M_{\mathrm{r}} 65 \mathrm{kD}\right)$ from isolated platelet membranes using collagen affinity column chromatography and preparative gel electrophoresis. Type I collagen-induced platelet aggregation was inhibited by preincubation of platelets with polyand monoclonal antibodies reactive to our receptor $(12,13)$. The purified receptor does not react with either antifibronectin or anti-GP IIb/IIIa antibodies suggesting that the receptor is not a part of fibronectin or GPIIb/IIIa (12). Using partial amino acid sequence data of a $\mathrm{CNBr}$ peptide of purified $65 \mathrm{kD}$ receptor protein, recently we have cloned a cDNA strand that encodes the $65-\mathrm{kD}$ receptor protein from a human bone marrow cDNA library. A recombinant protein was obtained from a prokaryotic expression vector. The recombinant protein binds to type I collagen and inhibits type I collagen-induced platelet aggregation and the release of ATP in a dose-dependent manner (14).

In this investigation, we present evidence that a synthetic peptide of 18 amino acid residues (which we refer to as peptide-1) derived from the cloned receptor inhibits the type I collagen-induced platelet aggregation and the release of ATP in a dose-dependent manner. The peptide- 1 also reacts with polyand monoclonal antibodies raised against the purified platelet $65-\mathrm{kD}$ protein. The peptide does not react with platelet type III collagen receptor antibody. These antibodies previously were reported to specifically inhibit types I and III collageninduced platelet aggregation and the release of ATP, respectively $(13,15)$. Radiolabeled peptide-1 specifically binds to type I collagen but not type III collagen. These results provide evidence that the $65-\mathrm{kD}$ protein is involved in the interaction of platelets with type I collagen and that there are different platelet receptor sites of interaction for different types of collagen.

\section{Methods}

Preparation of platelet-rich plasma ( $P R P)$. Human blood (nine parts) was collected from normal volunteers after an overnight fast in polypropylene tubes containing one part $3.8 \%$ sodium citrate. PRP was prepared by centrifuging the citrated blood at room temperature for $10 \mathrm{~min}$ at $226 \mathrm{~g}$ (16). Whole blood and PRP were exposed to plas- 
tic surfaces or siliconized vessels only. Platelet counts of the PRP ranged from 200,000 to 300,000 per $\mathrm{mm}^{3}$.

Platelet aggregometry. Platelet aggregation was studied by the turbidimetric method of Born (17) using a ChronoLog Lumi aggregometer (Chrono-log Corp. Havertown, PA).

Preparation of human platelet membranes. Platelet membranes were prepared according to the method developed by Barber and Jamieson (18). Protein concentration in samples was determined by the method of Lowry et al. (19).

Preparation of types I and III collagen. Collagen was prepared from human placenta according to Seyer et al. $(20,21)$. The concentration of the collagen solutions was determined by amino acid analysis after $6 \mathrm{~N} \mathrm{HCl}$ hydrolysis (22).

Binding of $\left[{ }^{125}\right.$ I]peptide-1 to type I collagen-coated microtiter wells. Since peptide- 1 contains two tyrosine residues in the sequence, we radiolabeled the peptide by iodination using the chloramine $\mathrm{T}$ method (23). Microtiter wells were coated with type I collagen, type III collagen, or fibronectin, followed by $0.1 \%$ BSA as described previously (14).

Assays for the binding of $\left[{ }^{125} \mathrm{I}\right]$ peptide- 1 to type I collagen- or type III collagen-coated microtiter wells were performed in $50 \mathrm{mM}$ phosphate buffer, $\mathrm{pH} 7.4$, at $37^{\circ} \mathrm{C}$. The assay mixtures contained $150 \mu \mathrm{l}$ of the buffer and $50 \mathrm{nM}\left[{ }^{125} \mathrm{I}\right]$ peptide- 1 , and were incubated for varying lengths of time as indicated in the text. In some experiments, various amounts of other peptides were added to the mixture as specified in the text. After a specified period of incubation, wells were washed seven times with binding buffer, detached with $100 \mu$ (twice) of $2 \%$ SDS/10 mM EDTA, and the radioactivity in the combined solution was assessed with a gamma counter. Preliminary experiments indicated that $90.1 \%$ of the total bound radioactivity could be readily displaced by incubation with 100 -fold molar excess of unlabeled peptide-1. The displaced counts were considered to be specific binding and the undisplaced counts were considered to be bound nonspecifically. Each value of $\left[{ }^{125} \mathrm{I}\right]$ peptide- 1 bound to the microtiter well plates was corrected for nonspecific binding.

Labeling of platelets with $\left[{ }^{14} \mathrm{C}\right]$ serotonin. An aliquot $(20 \mu \mathrm{l})$ of $\left[{ }^{14} \mathrm{C}\right]$ serotonin (sp. act. $\left.51.5 \mathrm{mCi} / \mathrm{mmol}\right)$ was added into PRP $(20 \mathrm{ml})$ and incubated at room temperature for $30 \mathrm{~min}$. At the end of the incubation, an equal volume of $20 \mathrm{mM}$ Tris- $\mathrm{HCl}-130 \mathrm{mM} \mathrm{NaCl}-1 \mathrm{mM}$ EDTA, pH 7.4 (Tris-EDTA) was added and centrifuged at $500 \mathrm{~g}$ for $10 \mathrm{~min}$. The pellets were suspended in $20 \mathrm{ml}$ Tris-EDTA and centrifuged again. The pellets were suspended in Tris-EDTA at a concentration of 400,000-600,000 platelets $/ \mathrm{mm}^{3}$ (16).

Adhesion of platelets to artificial matrix and denuded aorta segments. An aliquot $(1 \mathrm{ml})$ of each test peptide (peptide- 1 or control peptide) was put on artificial matrix (rat type I collagen)-coated petri dishes $(60 \mathrm{~mm}$, Collaborative Biomedical Products, Bedford, MA) and incubated at room temperature for $10 \mathrm{~min}$. At the end of incubation, an aliquot of washed $\left[{ }^{14} \mathrm{C}\right]$ labeled platelets was added to each petri dish and incubated for additional $10 \mathrm{~min}$. These petri dishes were washed five times $(2 \mathrm{ml}$ each $)$ with Tris-EDTA. The attached platelets were detached with $10 \mathrm{ml}$ ScintiVerse BD (2 ml per time). Radioactivity was assessed with a Packard Scintillation counter (Packard, Downers Grove, IL) (14).

For the adhesion of platelets to rabbit aortic segments, rabbit aorta were dissected from surrounding tissues with scissors, the endothelium denuded with rubber policeman, and cut into segments. Aortic segments ( $800 \mathrm{mg}$ wet weight) were incubated with either peptide- 1 or control peptide for $10 \mathrm{~min}$. At the end of incubation, an aliquot of $\left[{ }^{14} \mathrm{C}\right]$ labeled platelets was added to each sample and incubated for additional $10 \mathrm{~min}$. The segments were washed with $12 \mathrm{ml} \mathrm{(3 \textrm {ml }}$ per time) Tris-EDTA buffer and the radioactivity was measured in a scintillation counter in the presence of $10 \mathrm{ml}$ of ScintiVerse BD.

Enzyme-linked immunosorbent assay. Microtiter plates were coated with $0.15 \mathrm{ml}$ of $0.05 \mathrm{M} \mathrm{Na}_{2} \mathrm{CO}_{3}, \mathrm{pH} 9.6$, containing $10 \mu \mathrm{g} / \mathrm{ml}$ of peptide-1, $-2,-3$, or platelet membranes (14). The plate was incubated at $37^{\circ} \mathrm{C}$ for $3 \mathrm{~h}$ and washed seven times with $0.15 \mathrm{M} \mathrm{NaCl}$ containing $0.05 \%$ Tween-20 (saline-Tween). Various dilutions of first antibody in $20 \mathrm{mM}$ phosphate- $130 \mathrm{mM} \mathrm{NaCl}-0.05 \%$ Tween 20 , $\mathrm{pH} 7.4$ (PBSTween) were added to each well and incubated at $37^{\circ} \mathrm{C}$ for $3 \mathrm{~h}$. Antibodies and inhibition reagents were incubated at $37^{\circ} \mathrm{C}$ for $30 \mathrm{~min}$ before being put into washed wells. The plate was again washed seven times with saline-Tween, and $0.15 \mathrm{ml}$ of peroxidase conjugated goat anti-rabbit or mouse IgG was added to each well. The plate was incubated at $37^{\circ} \mathrm{C}$ for $2 \mathrm{~h}$, washed with saline-Tween, and enzyme substrate (5-aminosalicyclic acid and $\mathrm{H}_{2} \mathrm{O}_{2}$ ) was added. The absorbance was read at $450 \mathrm{~nm}$.

\section{Results}

Peptide synthesis. We reasoned that the recognition site for type I collagen had to be located on the extra cellular domain of the $65-\mathrm{kD}$ receptor protein. Therefore, we have analyzed the deduced amino acid sequence of the cloned type I collagen receptor for the hydrophilicity diagram (Hope-Wood; Fig. 1 $A$ ) and for the domain structure (TopPred II; Fig. $1 B$ ). From these analyses, we infer that the protein contains three transmembrane domains (residues 1-21, 35-55, and 213-233 for domains I, II, and III, respectively) with a short $\mathrm{NH}_{2}$-terminal end and an extracellular domain (residues 56-212). We have chosen to synthesize two regions (peptide-1 and peptide-2) from the extracellular domain and one from the intracellular domain (peptide-3) for further studies. These peptides correspond to the sequences shown as follows: peptide-1 (residue 84-101, 18 mer): Arg-Arg-Ala-Asn-Ala-Ala-Leu-Lys-Ala-GlyGlu-Leu-Tyr-Lys-Cys-Ile-Leu-Tyr; peptide-2 (residue 142-162, 21 mer): Trp-Glu-Ala-Lys-Val-Gly-Glu-Leu-Leu-Gln-Ala-ArgSer-Ser-Arg-Pro-Ala-Trp-Gln-His-Ser; and peptide-3 (residue 261-278, 18 mer): Lys-Leu-Leu-Arg-Arg-Leu-Lys-Gly-GluAsp-His-Leu-Ser-Pro-Gly-Val-Gln-Asp.

Effect of the peptides on types I and III collagen-induced platelet aggregation and the release of ATP. A synthetic peptide containing the recognition site of the receptor for type I collagen should be able to inhibit type I collagen-induced platelet aggregation. We, therefore, investigated the effect of the peptides on type I collagen-induced platelet aggregation and the release of ATP. In the first set of experiments, effects of preincubation of type I collagen with varying amounts of peptide- 1 were tested. Preincubations were carried out in PBS for 15 minutes at $37^{\circ} \mathrm{C}$ without the addition of $2-\mathrm{mM} \mathrm{MgCl}_{2}$. The results are shown in Fig. $2 A$. Curve $a$ represents PRP stimulated with buffer or peptide-1, -2 , or -3 alone (negative control). Curve $b$ represents PRP stimulated with $0.5 \mu \mathrm{g}$ of type I collagen (positive control). Curves $c, d, e$, and $f$ show the effects of $10,20,30$, and $40 \mu \mathrm{g}$, respectively, of peptide- 1 on type I collagen-induced platelet aggregation and the ATP release. As can be seen, $40 \mu \mathrm{g}$ of peptide- 1 completely inhibits platelet aggregation induced by $0.5 \mu \mathrm{g}$ of type I collagen. The addition of 2-mM MgCl 2 to the incubation buffer had no effect on the peptide- 1 inhibition of type I collagen-induced platelet aggregation (data not shown). Peptide-2 and -3 had no effect on type I collagen-induced platelet aggregation or the release of ATP (data not shown). In contrast, peptide- 1 had no effect on type III collagen-induced platelet aggregation and ATP release (data not shown).

In the next set of experiments, we investigated the effects of preincubation of a fixed amount of peptide-1 $(40 \mu \mathrm{g})$ with varying amounts of type I collagen. As presented in Fig. 2 B, the inhibitory effect of $40 \mu \mathrm{g}$ of peptide- 1 could be partially reversed by $1 \mu \mathrm{g}$ and completely by $2 \mu \mathrm{g}$ of type I collagen. 

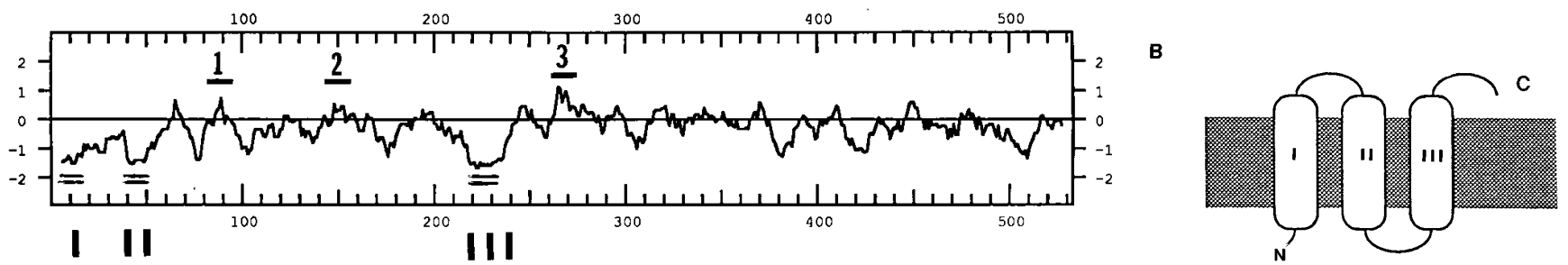

Figure. 1. Hydrophilicity and structural analyses of the cloned platelet receptor for type I collagen. The deduced amino acid sequence of the cloned platelet receptor for type I collagen was analyzed with a computer program for hydrophilicity (Hope-Wood, $A$ ) and for the domain structure (TopPred II, $B$ ). Membrane spanning segments are residues 1-21, 35-55, and 213-233 for domains I, II, and III, respectively and indicated by $=$ in $A$. The location of peptide-1, -2, and -3 is also indicated in $A$. The $\mathrm{NH}_{2}$-terminal end is located on outside.

Again, the presence of $2 \mathrm{mM} \mathrm{MgCl}_{2}$ in the incubation mixture had no effect on the inhibitory property of peptide- 1 . Taken together, these data demonstrate that the inhibitory effect of peptide- 1 is specific for type I collagen-mediated platelet ag-

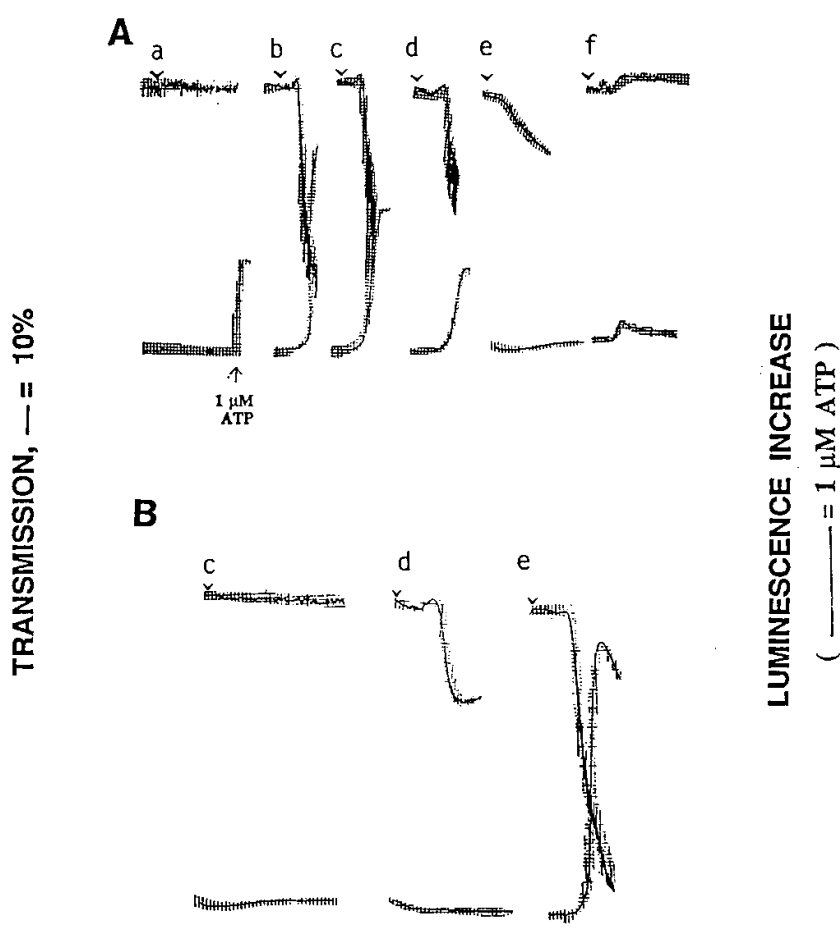

TIME, ( - = 1 Min. )

Figure. 2. Effects of synthetic peptide-1 on type I collagen-induced platelet aggregation and the release of ATP. In $A$, a fixed amount of type I collagen $(0.5 \mu \mathrm{g})$ was incubated with 0 (curve $b), 10 \mu \mathrm{g}$ (curve c), $20 \mu \mathrm{g}$ (curve $d$ ), $30 \mu \mathrm{g}$ (curve $e$ ), or $40 \mu \mathrm{g}$ (curve $f$ ) of peptide-1 in PBS for $15 \mathrm{~min}$ at $37^{\circ} \mathrm{C}$ before addition to PRP. The addition of $2 \mathrm{mM}$ $\mathrm{MgCl}_{2}$ to the incubation mixture had no effect. Curve $a$ represents buffer control. A standard solution ( $1 \mu \mathrm{M}$ ATP) was added at the end of curve $a(\uparrow)$ to calibrate luminescence. Addition of peptide-1, -2 , or -3 alone gave an identical result as buffer control. In $B$, a fixed amount of peptide- $1(40 \mu \mathrm{g})$ was preincubated with various amounts of type I collagen: $0.5 \mu \mathrm{g}$ (curve $c$ ), $1 \mu \mathrm{g}$ (curve $d$ ), and $2.0 \mu \mathrm{g}$ (curve $e$ ) in PBS for $15 \mathrm{~min}$ at $37^{\circ} \mathrm{C}$ before adding PRP. Platelet aggregometry was performed with a ChronoLog aggregometer. ATP release was monitored by luciferase method. gregation and that the inhibition is mediated through the peptide interaction with type I collagen.

In order to further test this idea, we next studied the effect of peptide- 1 on platelet aggregation mediated by other noncollagenous agonists. Various amounts of peptide- 1 ranging up to $40 \mu \mathrm{g}$ were used to test their effect on thrombin- and ADPinduced platelet aggregation. No significant effect could be appreciated for thrombin- and ADP-induced platelet aggregation (data not shown), further supporting the idea that peptide-1 effect on type I collagen-induced aggregation is mediated through its interaction with type I collagen.

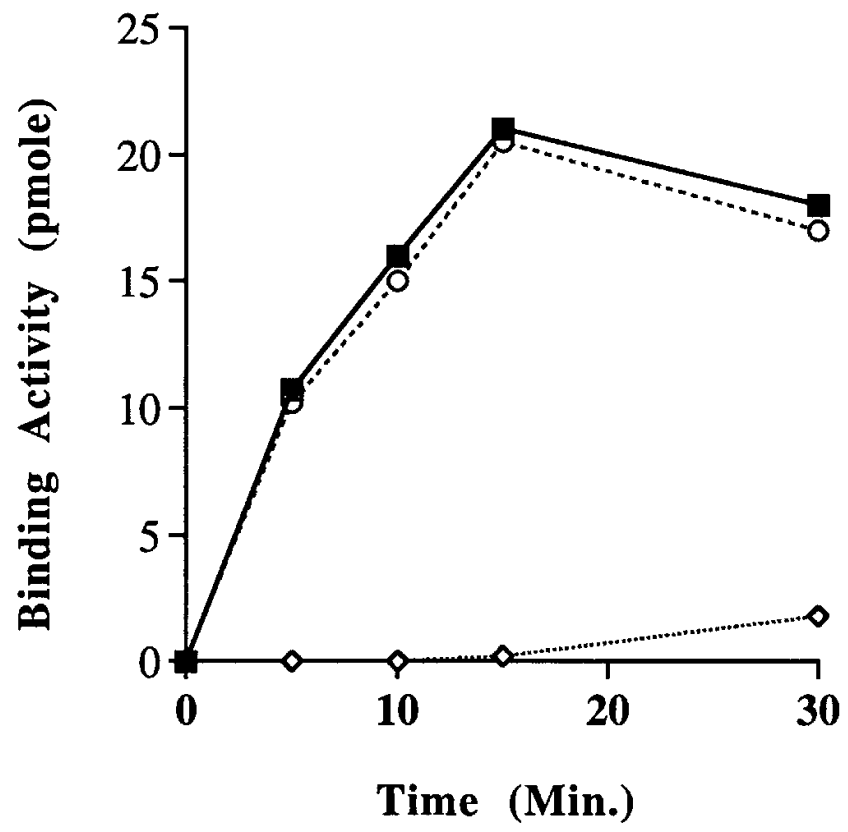

Figure. 3. Time-dependent binding of [ $\left.{ }^{125} \mathrm{I}\right]$ peptide- 1 by type I collagen in $50 \mathrm{mM}$ phosphate, $\mathrm{pH} 7.4(\mathbf{\square})$, and in $50 \mathrm{mM}$ phosphate, $\mathrm{pH}$ 7.4 , containing $2 \mathrm{mM} \mathrm{MgCl}_{2}(\bigcirc)$ or type III collagen $(\diamond)$-coated microtiter wells. An $150-\mu \mathrm{l}$ aliquot (50 $\left.\mathrm{nM}{ }^{[25} \mathrm{I}\right]$ peptide-1) was added to each microtiter well and incubated at $37^{\circ} \mathrm{C}$ for the times indicated in the figure (x-axis). At the end of incubation, each well was washed seven times with $150 \mu \mathrm{l}$ of $50 \mathrm{mM}$ phosphate buffer, $\mathrm{pH}$ 7.4. The radioactivity bound to each well was detached with $100 \mu \mathrm{l}$ 2\% SDS followed by $100 \mu l$ ScintiVerse BD (twice). Radioactivity in the combined washes was assessed by a gamma counter. Data are expressed as average of duplicate experiment. 


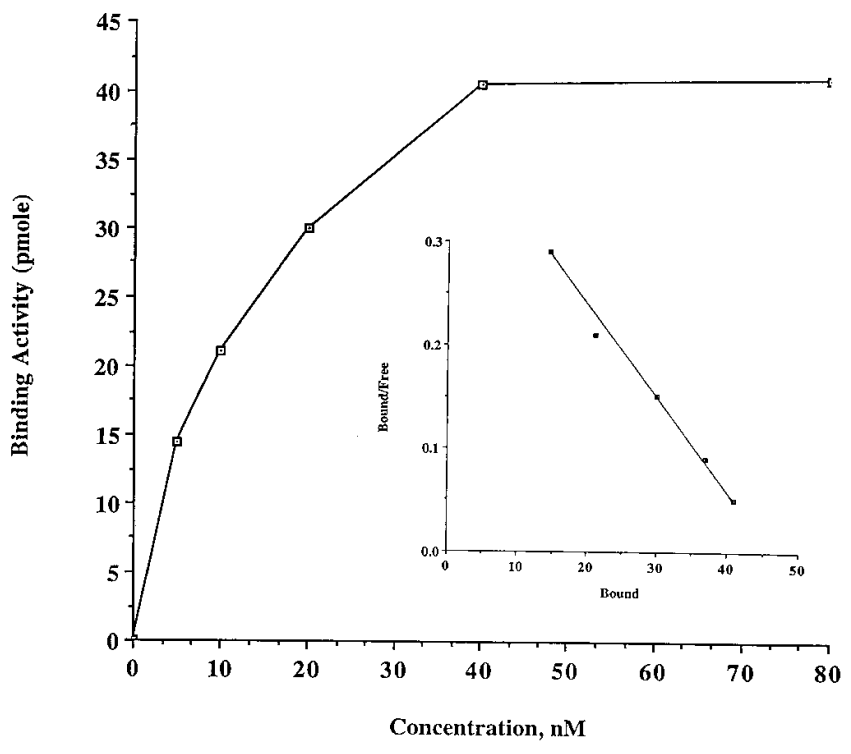

Figure. 4. Concentration-dependent binding of [ $\left.{ }^{125} \mathrm{I}\right]$ peptide-1 by type I collagen. The concentration (nM) of peptide- 1 in the binding assay is shown in the $\mathrm{x}$-axis. The amount of peptide- 1 bound is shown in y-axis. The inset is the Scatchard plot (the ratio, bound/free, is plotted as a function of bound peptide- 1 according to the method of Scatchard [24]). B, amount of peptide-1 bound (pmole) to type I collagencoated microtiter wells. F, concentration of free peptide-1 (nM).

Binding of I25IJpeptide-1 to type I collagen-coated microtiter wells. In order to investigate whether peptide-1 can directly bind to type I collagen, we have iodinated peptide- 1 and used it in a binding assay. As shown in Fig. 3, the binding of $\left[{ }^{125}\right.$ I]peptide-1 to type I collagen is time-dependent, reaching the maximum in $15 \mathrm{~min}$. Under identical conditions of experiments as used for binding to type I collagen, no significant specific binding of [ $\left.{ }^{125} \mathrm{I}\right]$ peptide- 1 to type III collagen-coated wells could be detected. The addition of $2 \mathrm{mM} \mathrm{MgCl}_{2}$ to the binding assay buffer does not affect the binding to type I collagen. The binding of $\left[{ }^{125} \mathrm{I}\right]$ peptide- 1 to type I collagen-coated microtiter wells is concentration dependent (Fig. 4). The dissociation constant $\left(K_{\mathrm{d}}=10 \mathrm{nM}\right)$ of the binding was determined by Scatchard analysis (Fig. 4, inset) (24).

Reactivity of the synthetic peptides with anti-65 kD antibodies. Next, we investigated whether these synthetic peptides (peptide-1, -2, and -3) could be recognized by polyclonal and monoclonal antibodies raised against the purified platelet type I collagen receptor $\left(M_{\mathrm{r}} 65 \mathrm{kD}\right)$ and polyclonal anti-type III collagen receptor $\left(M_{\mathrm{r}} 47 \mathrm{kD}\right)$ using an ELISA (Fig. 5). We have shown previously that polyclonal and monoclonal anti-65 kD antibodies used in this study inhibit specifically type I collagen-induced platelet aggregation and the release reaction $(12,13)$ and that anti-47 $\mathrm{kD}$ antibodies inhibit specifically type III collagen-induced platelet aggregation and the release of ATP (15). All three peptides were recognized by the polyclonal anti-65 kD antibodies to a varying degree. However, only peptide- 1 reacted with the monoclonal anti- $65 \mathrm{kD}$ antibodies. There was no reactivity between peptide-1, peptide-2, and peptide -3 , and the anti- $47 \mathrm{kD}$ polyclonal antibodies. These results further suggest that there are different reactive sites on human platelets for interaction with type I and type III collagens.
Effect of the synthetic peptides on the binding of purified anti-65 $\mathrm{kD} \operatorname{IgG}$ to intact platelets. We have used flow cytometry to determine if the synthetic peptides can inhibit the binding of monoclonal anti-65 kD IgG to washed intact platelets. Result shows a shift in the log fluorescence intensity to the right when platelets are incubated with anti- $65 \mathrm{kD}$ IgG compared to buffer control. Peptide-1, but not peptide-2 or peptide- 3 , inhibits the binding of anti- $65 \mathrm{kD}$ IgG to platelets (data not shown).

Adhesion of platelets to artificial matrix. We have used type I collagen artificial matrix-coated dishes to test the effect of these peptides on the adhesion of platelets (Fig. 6). The inhibitory effect was seen with peptide- 1 and shown to be dosedependent. It reaches the maximum inhibition at a dose of $60 \mu \mathrm{g}$. There is no significant inhibitory effect by either peptide- 2 or peptide- 3 . The addition of $2-\mu \mathrm{M} \mathrm{PGE}_{2}$ or $100-\mu \mathrm{M}$ RGDS has no effect on the adherence of labeled platelets to type I collagen in this assay system. The decreases in the adhesion of platelets to collagen is not caused by the release of labeled $\left[{ }^{14} \mathrm{C}\right]$ serotonin from the platelets. We have performed a parallel experiment under the same condition and the release of $\left[{ }^{14} \mathrm{C}\right]$ serotonin is not significant.

We compared peptide- 1 with peptide- 3 and the polyclonal and monoclonal antibodies raised against the purified platelet $65-\mathrm{kD}$ protein for their inhibitory effect on the adhesion of plate-

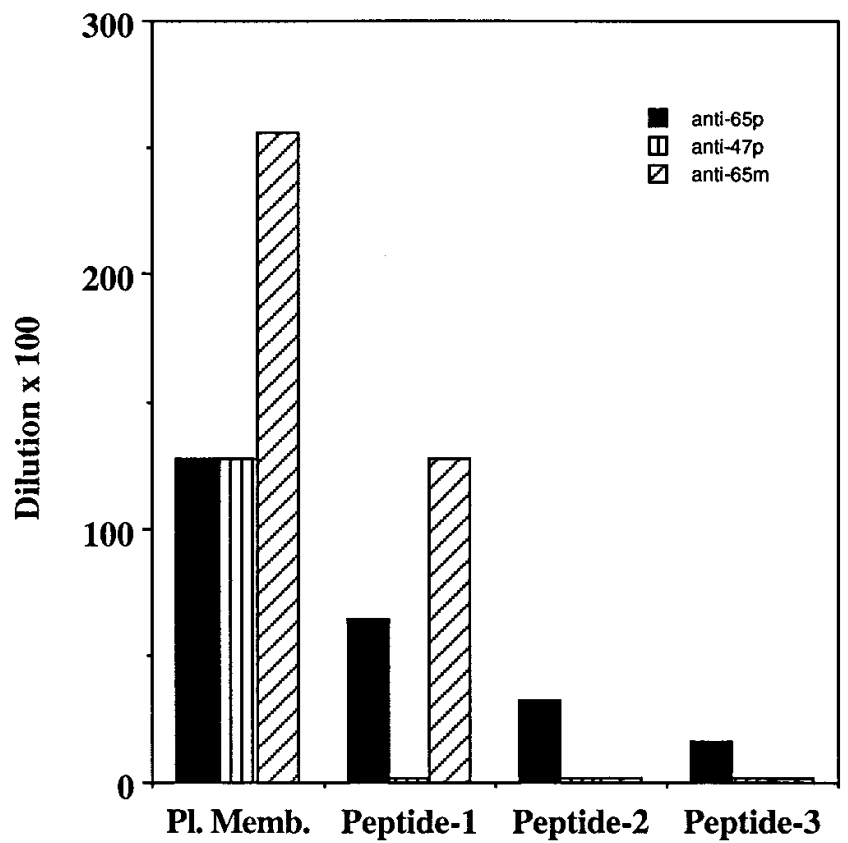

\section{Coating Material}

Figure 5. Reactivity of synthetic peptide-1, -2 , and -3 with polyclonal anti-type I collagen receptor antibodies (anti-65p), monoclonal antitype I collagen receptor antibodies (anti- $65 \mathrm{~m}$ ) and polyclonal antitype III collagen receptor antibodies. The microtiter plates were coated with either platelet membranes, peptide-1, peptide-2, or peptide- 3 and tested for reactivity with antibodies indicated by ELISA. The y-axis shows the highest dilution of antibodies that gave an ELISA reading $>0.1$. Detailed procedures are described in Methods. Data shown are average of a duplicate experiment representative of two separate sets of ELISA that yielded similar results. 


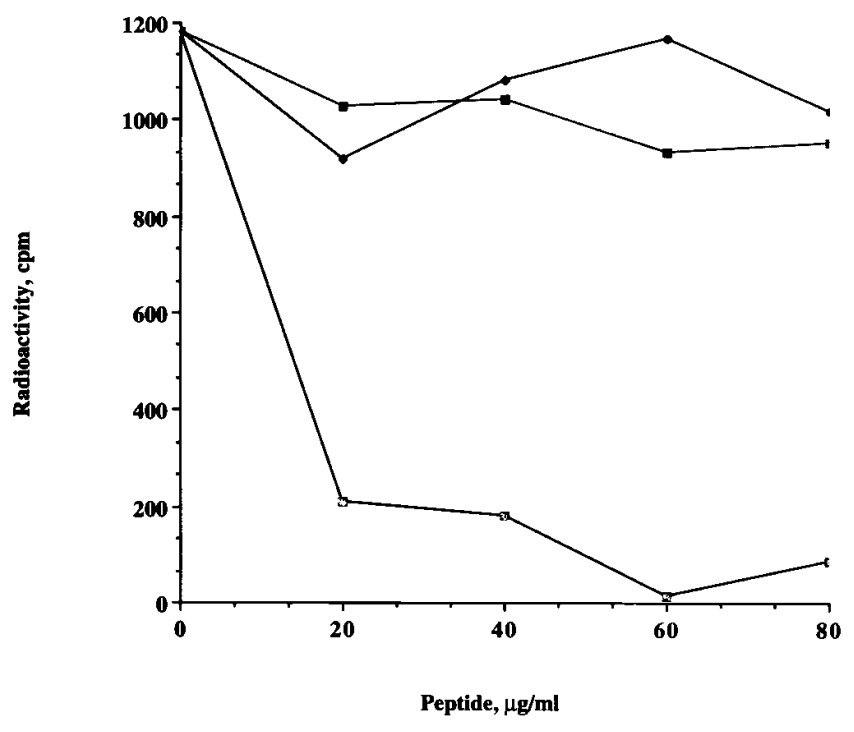

Figure 6. Inhibition of peptides on the adhesion of platelets on artificial matrix. Petri dishes $(100 \mathrm{~mm}$, coated with rat tendon type I collagen) were incubated with various amounts of peptides dissolved in $2 \mathrm{ml}$ Tris-EDTA (listed in x-axis, peptide-1 (open circles), peptide- 2 (filled-in squares), and peptide-3 (filled-in diamonds), for $15 \mathrm{~min}$ at room temperature. An aliquot of $1 \mathrm{ml}$ of $\left[{ }^{14} \mathrm{C}\right]$ labeled platelets was added to dishes (duplicate) and incubated for another $15 \mathrm{~min}$ on shaker as described in Methods. Data shown are average of one duplicate experiment representative of two that gave similar results.

lets to type I collagen matrix (Table I). At one dose tested, peptide-1 (80\% inhibition) as well as polyclonal (80\%) and monoclonal antibodies $(60 \%)$ inhibit the adhesion of platelets on the artificial type I collagen-coated dishes.

We have also studied the effect of the peptide- 1 , peptide-2, and peptide- 3 on the adhesion of platelets to rabbit aortic segments. Peptide- 1 , but not peptide- 2 or peptide- 3 , inhibits the adhesion of platelets to aortic segments in a dose-dependent manner (Fig. 7). At the highest dose of the peptide-1, $\sim 50 \%$ of labeled platelets is not inhibited by the peptide- 1 . The inhibitory effect of the peptide- 1 reached the maximal level at 160 $\mu \mathrm{g} / \mathrm{ml}$. There is no inhibitory effect on platelet adhesion to aortic segments by peptide- 2 or peptide- 3 .

Table I. Effect of Various Agents on the Adhesion of Platelets on Artificial Type I Collagen Matrix

\begin{tabular}{lcc}
\hline \multicolumn{1}{c}{ Agents } & Radioactivity (cpm) & $\begin{array}{c}\text { Percent } \\
\text { inhibition }\end{array}$ \\
\hline Control (BSA $40 \mu \mathrm{g} / \mathrm{ml})$ & $563(517,609)$ & 0 \\
Peptide-1, $40 \mu \mathrm{g} / \mathrm{ml}$ & $121(132,110)$ & 79 \\
Peptide-2, $40 \mu \mathrm{g} / \mathrm{ml}$ & $391(331,452)$ & 30 \\
Monoclonal IgG, $40 \mu \mathrm{g} / \mathrm{ml}$ & $383(421,346)$ & 32 \\
Polyclonal antiserum, $1 / 200$ & $143(130,155)$ & 75
\end{tabular}

Type I collagen coated petri dishes ( $60 \mathrm{~mm}$, Biocoat Cellware) were incubated with the agents listed above for $10 \mathrm{~min}$ at room temperature. An aliquot of $\left[{ }^{14} \mathrm{C}\right]$ labeled platelets $(7,685 \mathrm{cpm})$ was added to each dish and incubated at room temperature for another $15 \mathrm{~min}$ with gentle shaking as described in Methods. Data are the average of duplicate experiments (the actual cpm are in parentheses).

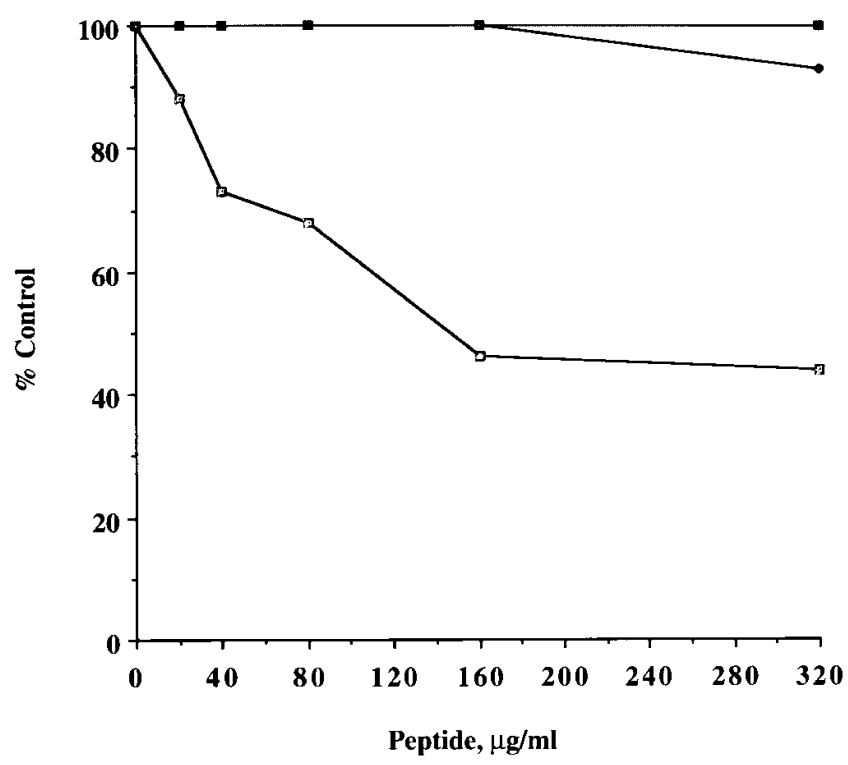

Figure 7. Dose-dependent inhibition of peptide- 1 on the adhesion of platelets to rabbit aortic segments. Wet weight $(0.8 \mathrm{~g})$ of rabbit aortic segments were incubated with peptide-1 (open circles), peptide-2 (filled-in squares), and peptide-3 (filled-in diamonds) for $15 \mathrm{~min}$ at room temperature. At the end of incubation, an aliquot of washed $\left[{ }^{14} \mathrm{C}\right]$ serotonin-labeled platelets $(1 \mathrm{ml})$ was added to each tube and incubated for another $15 \mathrm{~min}$ at room temperature with gentle shaking as described in Methods. Data are average of three single experiments.

\section{Discussion}

Recently, we have reported that platelet type I collagen receptor $(65 \mathrm{kD})$, a nonintegrin platelet protein was cloned from human bone marrow cDNA library. The cloned cDNA was expressed in a prokaryotic expression system and the expressed recombinant protein was purified. The purified recombinant protein inhibits type I collagen but not type III collagen-induced platelet aggregation in a dose-dependent manner (14). The amino acid sequence was deduced from the nucleotide sequence. Based on computer analyses for hydrophilicity and domain structures, we have synthesized three peptides for investigation as a potential recognition site for type I collagen. Two of the peptides, peptide- 1 and peptide- 2 , are from the extracellular domain, and peptide- 3 is from a cytoplasmic domain. Peptide-1 inhibited type I collagen-induced platelet aggregation and the release of ATP. Peptide- 2 and peptide- 3 had no effect. [ $\left.{ }^{125} \mathrm{I}\right]$ labeled peptide- 1 bound to type I collagen in a time- and concentration-dependent manner with $K_{\mathrm{d}}$ of $10 \mathrm{nM}$. The binding could be displaced with nonlabeled peptide-1 (100-fold excess) suggesting that the binding is specific. In an ELISA system, peptide-1 was shown to be reactive with monoclonal anti- $65 \mathrm{kD}$ antibody. Lastly, peptide-1 could inhibit binding of monoclonal anti-65 kD antibody to intact platelets as assayed by flow cytometry. In contrast, radiolabeled peptide- 1 did not bind to type III collagen. Nor did the peptide inhibit type III collagen-induced platelet aggregation and the release of ATP. In addition, peptide- 1 is not recognized by type III collagen receptor antibody (anti- $47 \mathrm{kD}$ polyclonal antibody). Together, these results support the idea that peptide- 1 
encompasses recognition site of the $65-\mathrm{kD}$ receptor for type I collagen.

The inhibitory effect of peptide- 1 on type I collagen-induced platelet aggregation did not result from nonspecific toxicity of the peptide. We have tested the viability of platelets in response to 4- $\mu \mathrm{M}$ ADP with the highest amount of peptide-1 used in the aggregation studies. ADP- and thrombin-induced platelet aggregation is not affected by peptide- 1 . Peptide- 2 or peptide-3 also did not inhibit ADP- and thrombin-induced platelet aggregation. In addition, none of these peptides inhibited type III collagen-induced platelet aggregation. It is unlikely that the ability of peptide- 1 to inhibit type I collageninduced platelet aggregation is due to peptide toxicity.

Peptide- 1 inhibits the adhesion of platelets to type I collagen-coated petri dish by $90 \%$ (Fig. 6). However, the adhesion of platelets to rabbit aortic segments was inhibited by only $50 \%$ (Fig. 7). The reason for the discrepancy may be ascribable to the presence of other types of collagen, especially type III collagen, in aortic segments to which platelets can adhere. We have shown previously that the receptors for types I and III collagen are different (15).

A tetra peptide, DGEA, derived from type I collagen, $\alpha 1-$ CB3 has been isolated and showed to be an inhibitor of collagen-platelet interaction (25). The peptide requires $5 \mathrm{mM}$ to completely inhibit platelet adhesion to collagen. Its derivative, (GPHyPro)5-GADGEA (GPHyPro)5 is 10-30-fold more active than DGEA (26). In contrast, our peptide-1 completely inhibits type I collagen-induced platelet aggregation at 20-40 $\mu \mathrm{M}$. Peptide-1 is not an inhibitor for ADP-, type III collagen-, or thrombin-induced platelet aggregation suggesting that it is a specific inhibitor for type I collagen-platelet interaction.

In conclusion, the results from this investigation suggest that peptide- 1 is the active binding site on platelet receptor for type I collagen to interact with type I collagen based on the following observations: first, peptide- 1 binds to type I collagen specifically; second, peptide-1 inhibits type I collagen-induced platelet aggregation; third, peptide- 1 blocks the anti- $65 \mathrm{kD}$ antibody to interact with its receptor; and finally, peptide- 1 inhibits the adhesion of platelets to type I collagen matrix and aortic segments.

\section{Acknowledgments}

We wish to thank Ms. H. Le and Mr. J. West for their expert technical assistance, and Mr. B. Cassael for peptide synthesis.

This study was supported by research fund from Department of Veteran Affairs.

\section{References}

1. Staatz, W.D., S.M. Rajpara, E.A. Wagner, W.G. Carter, and S.A. Santoro. 1989. The membrane glycoprotein Ia-IIa (VLA-2) complex mediates the
$\mathrm{Mg}^{2+}$-dependent adhesion of platelets to collagen. J. Cell Biol. 108:1017-1024.

2. Kotite, N.J., S.A. Santoro, and L.W. Cunningham. 1984. Interaction of specific platelet membrane proteins with collagen: evidence from chemical cross-linking. Biochemistry. 23:3099-3104.

3. Chiang, T.M., and A.H. Kang. 1982. Isolation and purification of collagen $\alpha 1$ (I) receptor from human platelet membranes. J. Biol. Chem. 257:7581-7586.

4. Deckmyn, E., E. von Houtte, and J. Vermylen. 1992. Disturbed platelet aggregation to collagen associated with an antibody against an 85/90 kDa platelet glycoprotein in a patient with prolonged bleeding time. Blood. 79:14661471 .

5. Tandon, N.N., U. Kralisz, and G.A. Jamieson. 1989. Identification of glycoprotein IV (CD 36) as a primary receptor for platelet-collagen adhesion. $J$. Biol. Chem. 264:7576-7583.

6. Moroi, M., S.M. Jung, M. Okuma, and K. Shinmyozu. 1989. A patient with platelets deficient in glycoprotein VI that lack both collagen-induced aggregation and adhesion. J. Clin. Invest. 84:1440-1445.

7. Staatz, W.D., K.F. Fok, M.M. Zutter, S.P. Adams, B.A. Rodriguez, and S.A. Santoro. 1991. Identification of a tetrapeptide recognition sequence for the $\alpha 2 \beta 1$ integrin in collagen. J. Biol. Chem. 266:7363-7367.

8. Ruoslahti, E., and M.D. Pierschbacher. 1987. New perspectives in cell adhesion: RGD and integrins. Science (Wash. DC). 238:491-497.

9. Yamada, K.M. 1991. Adhesion recognition sequence. J. Biol. Chem. 266: 12809-12812.

10. Gartner, T.K., and J.S. Bennett. 1985. The tetrapeptide analogue of the cell attachment site of fibronectin inhibits platelet aggregation and fibrinogen binding to activated platelets. J. Biol. Chem. 260:11891-11894.

11. Davis, G.E. 1992. Affinity of integrins for damaged extracellular matrix. v $\beta 3$ binds to denatured collagen type I through RGD sites. Biochem. Biophys. Res. Commun. 182:1025-1031.

12. Chiang, T.M., A.H. Kang, J.M. Dale, and E.H. Beachey. 1984. Immunological studies of the purified human platelet receptor for the $\alpha 1$ (I)-chain of chick skin collagen. J. Immunol. 133:872-876.

13. Chiang, T.M., A. Jin, and A.H. Kang. 1987. Platelet-collagen interaction: inhibition by a monoclonal antibody raised against collagen receptor. $J$. Immunol. 139:887-892.

14. Chiang, T.M., A. Rinaldy, and A.H. Kang. 1997. Cloning, characterization, and functional studies of a non-integrin platelet receptor for type I collagen. J. Clin. Invest. 100:514-521.

15. Chiang, T.M., J.M. Seyer, and A.H. Kang. 1993. Collagen-platelet interaction: separate receptor sites for types I and III collagen. Thromb. Res. 71: 443-456.

16. Chiang, T.M., E.H. Beachey, and A.H. Kang. 1976. Interaction of a chick skin collagen fragment ( $\alpha 1-\mathrm{CB} 5)$ with human platelets. Biochemical studies during the aggregation and release reaction. J. Biol. Chem. 250:6916-6922.

17. Born, G.V.R. 1962. Aggregation of platelets by adenosine diphosphate and its reversal. Nature (Lond.). 194:927-929.

18. Barber, A.J., and G.A. Jamieson. 1970. Characterization of plasma membranes from human platelets. J. Biol. Chem. 245:6357-6365.

19. Lowry, O.H., H.J. Rosebrough, A.L. Farr, and R.J. Randall. 1951. Protein measurement with the folin phenol reagent. J. Biol. Chem. 193:265-275.

20. Seyer, J.M., C. Mainardi, and A.H. Kang. 1980. Covalent structure of collagen: amino acid sequence of $\alpha 1$ (III)-CB5 from type III collagen of human liver. Biochemistry. 9:1583-1589.

21. Seyer, J.M., and A.H. Kang. 1981. Covalent structure of collagen: amino acid sequence of $\alpha 1$ (III)-CB9 from type III collagen of human liver. Biochemistry. 20:2621-2627.

22. Bergman, I., and R. Laxley. 1963. Two improved and simplified methods for the spectrophotometric determination of hydroxyproline. Anal. Chem. 35:1961-1965.

23. Hunter, W.M. 1978. Radioimmunoassay. In Handbook of Exptl. Immunol. D.M. Weir, editor. Blackwell Publishers, Oxford, United Kingdom. 14.114.40 .

24. Scatchard, G. 1949. The attractions of proteins for small molecules and ions. Ann. NY Acad. Sci. 51:660-672.

25. Staatz, W.D., J.J. Walsh, T. Pexton, and S.A. Santoro. 1990. The $\alpha 2 \beta 1$ integrin cell surface collagen receptor binds to the $\alpha 1$ (I)-CB3 peptide of collagen. J. Biol. Chem. 265:4778-4781.

26. Santoro, S.A., M.M. Zutter, J.E. Wu, W.D. Staatz, E.U.M. Saelman, and P.J. Kelley. 1994. Analysis of collagen receptors. Methods Enzymol. 245:147-183. 